\title{
Altitudinal variation for B chromosome frequency in the characid fish Astyanax scabripinnis
}

\author{
DANIELA MORILHA NÉO†, ORLANDO MOREIRA FILHO*† \\ \& JUAN PEDRO M. CAMACHO \\ $\dagger$ †epto. de Genética e Evolução, Universidade Federal de São Carlos, CP: 676, 13565-905 São Carlos, \\ $S P$, Brazil and $\$$ Departamento de Genética, Universidad de Granada, 18071 Granada, Spain
}

\begin{abstract}
The analysis of three populations of the characid fish Astyanax scabripinnis located at different altitudes along the same stream has revealed the presence of a macro B chromosome in two highaltitude populations $(1800 \mathrm{~m}$ and $1920 \mathrm{~m})$ but its absence from a low-altitude population $(700 \mathrm{~m})$. Because the stream flows through very rugged mountains, with numerous falls ensuring that any gene flow occurs downstream only, the absence of B chromosomes from the low-altitude populations is best interpreted in the light of the parasitic theory of B chromosome evolution. Under this theory, we would expect $\mathrm{B}$ chromosomes to be more frequent where environmental conditions are more favourable for the species, because Bs are best tolerated there. The widespread presence of these B chromosomes in numerous Brazilian river headwaters, which are the preferred habitat for this species, support this possibility.
\end{abstract}

Keywords: Astyanax scabripinnis, B chromosomes, heterochromatin, isochromosome.

\section{Introduction}

B chromosomes are 'additional dispensable chromosomes that are present in some individuals from some populations in some species, which have probably arisen from the A chromosomes but follow their own evolutionary pathway' (Camacho \& Parker, 1993, in Beukeboom, 1994). It is their irregular mitotic and meiotic behaviour that allows them to accumulate selfishly in the germ line of many species (Jones, 1991).

The only two models of B-chromosome evolution that have traditionally been accepted are the parasitic (Östergren, 1945; Nur, 1966, 1977; Jones, 1985; Shaw \& Hewitt, 1990) and the heterotic (White, 1973) models. Both assume that B frequency in natural populations is in equilibrium, but differ in the causes promoting it. The parasitic model states that $\mathrm{B}$ maintenance is primarily a result of $\mathrm{B}$ accumulation (drive) counteracting their decrease in frequency because of the detrimental effects caused by the B chromosome on the fitness of B carriers. Most B chromosomes analysed in detail fit this model (for review, see Camacho et al. 2000). The heterotic

*Correspondence. E-mail: omfilho@power.ufscar.br model, however, involves a beneficial effect of nondriving Bs on the fitness of individuals carrying a low number of Bs, but detrimental effects on individuals with high $\mathrm{B}$ numbers. The only known $\mathrm{B}$ chromosomes probably being heterotic are those in the chive Allium schoenoprasum, which improve survival from seed to seedling (Holmes \& Bougourd, 1989) because they boost germination rate under drought conditions (Plowman \& Bougourd, 1994), and in the fungus Nectria haematococca, where Bs favour its pathogenicity (Miao et al., 1991). In the latter species, no population dynamics studies have been performed.

A third possibility has emerged in recent years after intensive population studies in the grasshopper Eyprepocnemis plorans (Camacho et al., 1997); that parasitic $\mathrm{B}$ chromosomes may be neutralized by the evolution of genes in the A genome suppressing the $\mathrm{B}$ drive. The possibility of the regeneration of neutralized B polymorphisms by the appearance of a new B-typepossessing drive illuminates possible pathways of the long-term evolution of parasitic B chromosomes (Camacho et al., 1997; Johnson, 1997; Zurita et al., 1998).

The characid fish Astyanax scabripinnis shows a widespread geographical distribution and is found in most Brazilian river basins. Astyanax scabripinnis, a 
species typical of stream headwaters, decreases in abundance downstream (Caramaschi, 1986). Large metacentric B chromosomes, similar in size to the largest autosome, have been described in several populations of this species (Maistro et al., 1992; Salvador \& Moreira Filho, 1992; Vicente et al., 1996; Mizoguchi \& Martins Santos, 1997), in parallel with the occurrence of B microchromosomes (Rocon Stange \& Almeida Toledo, 1993; Mizoguchi \& Martins Santos, 1997).

In this paper, we provide evidence that the metacentric macro-B chromosome of A. scabripinnis is frequent at the headwaters of a river, which constitute the most appropriate environment for this species, but is absent from a low-altitude population that constitutes the ecological limit of its distribution.

\section{Materials and methods}

A total of 672 specimens of the characid fish Astyanax scabripinnis were collected from three populations along the Ribeirão Grande stream [Paraiba do Sul basin, Campos do Jordão mountains (Sierra Mantiqueira), SP, Brazil]. Two populations were located on the mountain top, at the headwaters of the stream, but at different altitudes: $1920 \mathrm{~m}$ (a small stream situated very close to the source of the river) and $1800 \mathrm{~m}$ (Santa Isabel Reservoir). The third population was in the Paraíba river valley, at $700 \mathrm{~m}$.

All individuals were prepared for cytological analysis, but only $37 \%$ of these showed mitotic divisions that permitted such analysis. Whereas sex was determined for all the animals by careful gonad examination, chromosomes could be analysed only in some of the specimens. Cytological analysis was performed in mitotic cells obtained by the techniques described by Bertollo et al . (1978) and Moreira Filho \& Bertollo (1990).

Contingency tables for B frequency comparisons between populations and sexes were analysed by the $\mathrm{R} \times \mathrm{C}$ program, which employs the Metropolis algorithm to obtain an unbiased estimate of the exact $P$-value (Raymond \& Rousset, 1995). In all cases, 20 batches of 5000 replicates were performed. The analyses of sex ratio and Hardy-Weinberg equilibrium were performed by chi-squared goodness-of-fit.

\section{Results}

The B chromosomes found in the Ribeirão Grande stream were of three types, the prevalent one being similar to that previously described in this species (Vicente et al., 1996). Thus, most B-carrying individuals harboured the metacentric macro-B roughly similar in size to the longest autosome $\left(\mathrm{B}_{\mathrm{M}}\right.$ in Fig. 1). A few individuals (four at $1800 \mathrm{~m}$ and three at $1920 \mathrm{~m}$ ) carried a submetacentric B similar in size to the former and thus presumably derived from it by means of a pericentric inversion ( $\mathrm{B}_{\mathrm{SM}}$ in Fig. 1). A single individual from the $1920 \mathrm{~m}$ population carried a shorter metacentric B $\left(B_{m}\right.$ in Fig. 1). Because the two latter $B$ types were scarce and presumably derived from the principal type, the following analyses of B frequency were performed with the three $\mathrm{B}$ types considered as a whole. The separate analysis of the $\mathrm{B}_{\mathrm{M}}$ type (data not shown) gave similar results to those shown below.

Table 1 shows the frequency of $\mathrm{B}$ chromosomes found in the three localities sampled at different altitudes. B chromosomes were present in the two highest populations but absent from that from $700 \mathrm{~m}$.

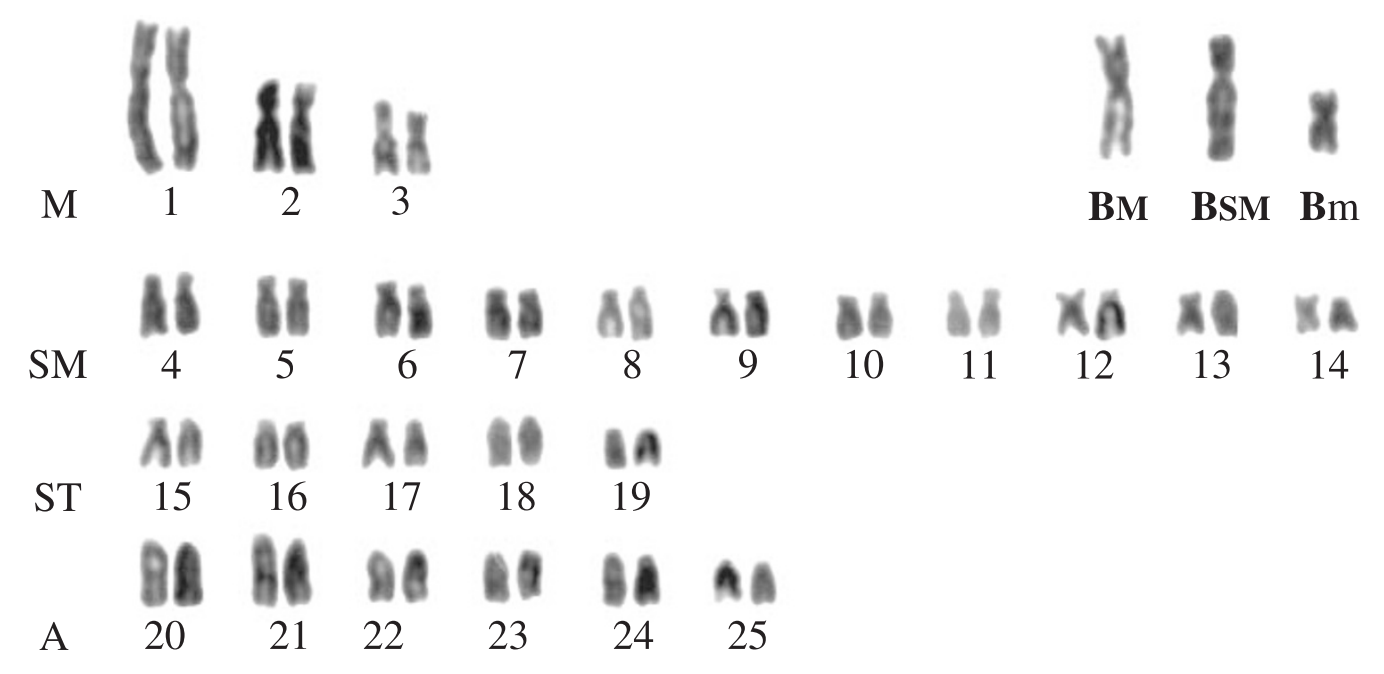

Fig. 1 Composition showing the karyotype of a female of the characid fish Astyanax scabripinnis carrying two B chromosomes, types $\mathrm{B}_{\mathrm{M}}$ and $\mathrm{B}_{\mathrm{m}}$, and a third $\mathrm{B}$ type, $\mathrm{B}_{\mathrm{SM}}$, from another individual.

(C) The Genetical Society of Great Britain, Heredity, 85, 136-141. 
Table 1 B chromosome frequency at three localities of the Ribeirão Grande situated at different altitudes at the Campos de Jordão region

\begin{tabular}{llrrrrrr}
\hline & \multicolumn{7}{c}{ Individuals $(n)$ with } \\
\cline { 2 - 7 } Altitude $(\mathrm{m})$ & Sex & $\mathrm{N}_{\mathrm{c}}$ & 0B & 1B & 2B & Total & Mean Bs \\
\hline 1920 & $\mathrm{~F}$ & 198 & 15 & 28 & 10 & 53 & 0.906 \\
& M & 119 & 30 & 17 & 3 & 50 & 0.460 \\
& Intersex & 1 & 0 & 1 & 0 & 1 & - \\
1800 & Total & 318 & 45 & 46 & 13 & 104 & 0.692 \\
& F & 88 & 22 & 15 & 1 & 38 & 0.447 \\
700 & M & 97 & 37 & 5 & 1 & 43 & 0.163 \\
& Total & 185 & 59 & 20 & 2 & 81 & 0.296 \\
& F & 81 & 33 & 0 & 0 & 33 & 0.000 \\
& M & 88 & 30 & 0 & 0 & 30 & 0.000 \\
& Total & 169 & 63 & 0 & 0 & 63 & 0.000 \\
\hline
\end{tabular}

$\mathrm{N}_{\mathrm{c}}=$ Number of individuals collected; $\mathrm{F}=$ female; $\mathrm{M}=$ male.

We analysed 63 individuals in the latter locality and all lacked B chromosomes, we can, therefore, deduce that the B frequency at $700 \mathrm{~m}$, if it is actually present, is lower than $4.75 \%$ (the $95 \%$ upper confidence limit, calculated from a Poisson distribution).

Because the specimens in each locality were collected over several years, a preliminary analysis of a possible temporal tendency to change in $\mathrm{B}$ frequency was performed. Neither at $1800 \mathrm{~m}$ (males: $P=1$; females: $P=0.809$ ) nor at $1920 \mathrm{~m}$ (males: $P=0.211$; females: $P=0.175)$ did any temporal tendency appear at a change in the frequency of B chromosomes. Therefore, the following analyses were performed on the entire sample in each locality.

$\mathrm{B}$ chromosomes were significantly more frequent at $1920 \mathrm{~m}$ than at $1800 \mathrm{~m}(P=0.00013)$. In addition, B frequency was higher in females than in males in the two B-carrying populations $(1800 \mathrm{~m}: P=0.00646 ; 1920 \mathrm{~m}$ : $P=0.00365$ ).

The frequencies of individuals with 0,1 and $2 \mathrm{~B}$ chromosomes fit Hardy-Weinberg expectations in both localities $\quad\left(1800 \mathrm{~m}: \quad \chi_{1}^{2}=0.038, \quad P=0.981 ; \quad 1920 \mathrm{~m}\right.$ : $\left.\chi_{1}^{2}=0.055, P=0.973\right)$. The same result was obtained when the analysis was performed for each sex separately (results not shown).

An analysis of the sex ratio, performed on the data of captured individuals $\left(\mathrm{N}_{\mathrm{c}}\right.$ in Table 1$)$, showed a significant excess of females at $1920 \mathrm{~m}$ altitude $\left(\chi_{1}^{2}=19.69\right.$, $P=0.000009)$ but not at $1800 \mathrm{~m}\left(\chi_{1}^{2}=0.44, P=0.508\right)$ or at $700 \mathrm{~m}\left(\chi_{1}^{2}=0.29, P=0.59\right)$.

\section{Discussion}

These results confirm previous research showing that the macro-B chromosomes in A. scabripinnis are more frequent in females than in males, so that there is a significant and positive association between carrying the B chromosome and being a female (Vicente et al., 1996). The observation of an individual carrying $1 \mathrm{~B}$ that showed ovotestes (see Table 1) even suggests that the B chromosome could, in some unknown way, interfere with sex determination and gonad development. This is reinforced by the observation of four other intersexes, all possessing $1 \mathrm{~B}$, in another population from a different river (D. Marco, personal communication). The higher $\mathrm{B}$ frequency in females could also be a result of the presence of the B chromosome causing higher early mortality among males, which would be consistent with this B being parasitic. These possibilities demand future research analysing $\mathrm{B}$ transmission, $\mathrm{B}$ effects on several fitness components, including viability, and B frequency at different ages in both sexes.

Previous cytogenetic studies in A. scabripinnis have shown the presence of macro-B chromosomes in a wide sample of small streams belonging to several different river basins (see Souza \& Moreira-Filho, 1995). In most cases where more than a single population was analysed, they belonged to different rivers running at different altitudes, thereby obscuring comparisons. The most informative comparison, however, is that between populations collected at different points from the same river. The only two such studies reported previously were inappropriate for frequency comparison because of small sample size (Souza \& Moreira-Filho, 1995) or a small altitude difference between populations (PortoForesti et al., 1997). Nevertheless, certain useful conclusions were provided by these studies. Souza \& Moreira-Filho (1995) analysed two populations from the Piracuama stream (Paraíba do Sul basin, Sao Paulo, Brazil) located at $1800 \mathrm{~m}$ and $780 \mathrm{~m}$ altitude. Although 
they analysed cytologically only 10 and 27 specimens, respectively, their results were adequate to document the presence of the macro-B at $1800 \mathrm{~m}$ but not at $780 \mathrm{~m}$. The analysis by Porto-Foresti et al. (1997) was performed on three samples collected at $880 \mathrm{~m}, 860 \mathrm{~m}$ and $820 \mathrm{~m}$ altitude from the Cascatinha stream, a small tributary of the Tietê river (Botucatu, SP, Brazil). Despite the small altitude range, these authors observed that the macro-B chromosome was most frequent at the highest site, which, as in the case of the Piracuama stream, corresponded to the headwaters of the stream.

The present results in the Ribeirão Grande stream, with a much larger sample size and broader altitude range, also indicate that the macro- $\mathrm{B}$ chromosome is most frequent in the headwaters $(1920 \mathrm{~m})$ and is absent at low altitude $(700 \mathrm{~m})$. At the intermediate altitude $(1800 \mathrm{~m}), \mathrm{B}$ frequency was lower than at the highest population. The best explanation for this result is provided by the parasitic theory (Östergren, 1945; Nur, 1966, 1977; Jones, 1985; Shaw \& Hewitt, 1990; Beukeboom, 1994; Camacho et al. 2000), by which B chromosomes are considered genome parasites maintained in populations as a result of drive mechanisms even though they might be harmful for the individuals carrying them. Under this theory, we would expect the highest B frequency in those localities with more favourable environments for the species, because there the burden of carrying these genome parasites would be best tolerated. Astanyax scabripinnis has been defined as a headwater species, whose presence in the small tributaries of many Brazilian rivers decreases downstream (Caramaschi, 1986). In this case, it is clear that the highest populations close to stream headwaters (e.g. Ribeirão Grande at $1920 \mathrm{~m}$, Piracuama at 1800 and Cascatinha at $880 \mathrm{~m}$ ) are situated in the most favourable places for this fish, where harbouring parasitic B chromosomes is more tolerable. The lowest populations (e.g. Ribeirão Grande at $700 \mathrm{~m}$ and Piracuama at $780 \mathrm{~m}$ ), however, represent populations at the ecological limit of the distribution of this species in each of these rivers. It is thus likely that certain ecological conditions make the presence of B chromosomes intolerable in these low-altitude sites. Although specific ecological analyses need to be performed, our field experience indicates the existence of two important ecological differences between high- and low-altitude localities: (i) the reduced presence of potential predators (e.g. the fishes Rhamdia hilarii, Gymnotus sp. and Hoplias malabaricus and aquatic insect larvae) in the high-altitude localities; and (ii) the lower fish species diversity at the high-altitude sites compared to low-altitude ones, indicating a stronger level of resource competition in the latter.

Altitudinal variation for B chromosome frequency has been described in other B chromosome systems; for instance, in the grasshopper Myrmeleotettix maculatus, Hewitt \& Ruscoe (1971) reported a steep cline for B frequency over the hillside of the Goginan mine (Wales), with B chromosomes being frequent in the valley bottom but very scarce on the hill at the head of the valley. The coincidence with a temperature cline in these populations, the geographical distribution of this B chromosome limited to the warmer and drier parts of Southern England and Wales, and the existence of selection against individuals carrying two B chromosomes (Shaw, 1984) clearly suggest that B chromosomes are more frequent in those places where environmental conditions determine a higher tolerance to these genome parasites.

In the grasshopper Omocestus bolivari, populations at high altitudes in the Sierra Nevada mountains (Granada, Spain) lack B chromosomes that are present at lower localities. On the basis of the frequent effect of B chromosomes slowing down development (Harvey \& Hewitt, 1979), this difference has been explained by the maladaptive effect of B chromosomes in high populations where the period of snow cover is longer and hence the time available for the life-cycle is shorter (Viseras \& Camacho, 1985).

In British populations of the plant Crepis capillaris, B chromosomes showed the highest frequency at midaltitudes in large populations, declining both towards the summit and in the small, isolated lowland populations (Parker et al., 1991). These authors suggested that B chromosomes in this species are excluded from populations growing under suboptimal conditions because of selection operating against individuals with one or more B chromosomes.

In the cases of M. maculatus (Hewitt 1976) and C. capillaris (Parker et al. 1989), it has been demonstrated that $\mathrm{B}$ chromosomes show strong drive, which explains why these $\mathrm{B}$ chromosomes may maintain themselves in natural populations despite being disfavoured by natural selection at the organism level. On this basis, and given the widespread presence of the A. scabripinnis macro-B chromosome in the headwaters of rivers in different Brazilian basins, such as Sapucaí (Salvador \& Moreira Filho, 1992; Vicente et al., 1996), Tietê (Maistro et al., 1992; Porto-Foresti et al., 1997), Paranapanema (Mizoguchi \& Martins Santos, 1997), Jucu (Rocon Stange \& Almeida Toledo, 1993), Paraíba do Sul (Souza \& Moreira-Filho, 1995; this paper), indicating that they constitute an old polymorphism, we can predict that this B chromosome is very likely to be a parasitic one, showing drive. In a recent report, Porto-Foresti et al. (1997) have pointed out the possibility that this $\mathrm{B}$ chromosome plays an adaptive role in this species and have suggested two alternative hypotheses to explain the higher B frequency in the 
higher stretch of the three analysed in the Cascatinha stream: (i) B chromosomes are harmful for fish living in the two lower stretches analysed, and (ii) B chromosomes confer a selective advantage on fish living in the highest stretch (Porto-Foresti et al., 1997). In our opinion, these two hypotheses are mutually compatible under the parasitic theory, because the same B chromosome might be harmful in a low-altitude population (thus reaching low frequency) but 'less-harmful' (not necessarily conferring a selective advantage) in a higher one (thus reaching higher frequency) simply for ecological reasons, as explained above. The precise ecological differences marking the different tolerances between populations remain to be identified, but it is clear that, for the moment, the parasitic theory provides us with the most complete picture for the evolutionary significance of B chromosomes in A. scabripinnis.

\section{Acknowledgements}

We are grateful to Dr João Evangelista (Instituto Florestal de Campos do Jordão, SP, Brasil) for help in collections, to FAPESP (Proc. no. 97/06590-0) for financial support and to Dr Luiz Antônio Carlos Bertollo for helpful suggestions on this work. JPMC would like to thank the FAPESP (Proc. no. 98/07271-8) for financial support for a brief stay at Sao Carlos (SP, Brazil) in 1998, and the Spanish Dirección General de Enseñanza Superior (PB96-1433) and Plan Andaluz de Investigación (Grupo no. CVI-165).

\section{References}

BERTOLLO, L. A. C., TAKAHASHI, C. AND MOREIRA FILHO, O. 1978. Cytotaxonomic consideration on Hoplias lacerdae (Pisces Erythrinidae). Braz. J. Genet., 1, 103-120.

BeUKeBoom, L. W. 1994. Bewildering Bs: an impression of the 1st B-Chromosome Conference. Heredity, 73, 328-336.

CAMACHO, J. P. M., SHARBEL, T. F. AND BEUKEBOOM, L. W. 2000. B chromosome evolution. Phil. Trans. R. Soc. Lond. B, 355, 163-178.

CAMACHO, J. P. M., SHAW, M. W., LÓPEZ-LEÓN, M. D., PARDO, M. C. AND CABrero, J. 1997. Population dynamics of a selfish B chromosome neutralized by the standard genome in the grasshopper Eyprepocnemis plorans. Am. Nat., 149, 10301050.

CAMAChO, J. P. M. AND PARKeR, J. 1993. First B Chromosome Conference. Miraflores de la Sierra, Madrid.

CARAMASChI, E. M. P. 1986. Distribução da ictiofauna de riachos das bacias do Tietê e do Paranapanema, junto ao divisor de águas (Botucatu, SP). Ph.D. Universidade Federal de São Carlos, SP Brazil.

HARVEY, A. W. AND HEWITT, G.M. 1979. B chromosomes slow development in a grasshopper. Heredity, 42, 397-401.
HEWITT, G. M. 1976. Meiotic drive for B chromosomes in the primary oocytes of Myrmeleotettix maculatus (Orthoptera: acrididae). Chromosoma, 56, 381-91.

HEWITT, G. M. AND RUSCOE, C. N. E. 1971. Changes in microclimate correlated with a cline for B-chromosomes in the grasshopper Myrmeleotettix maculatus. J. Anim. Ecol., 40, $753-765$.

HOLMES, D. S. AND BOUGOURD, S. M. 1989. B-chromosome selection in Allium schoenoprasum II. Natural populations. Heredity, 63, 83-87.

JOHNSON, N. A. 1997. Selfish genetic elements: long-range dynamics predicted by non-equilibrium models. Trends Ecol. Evol., 12, 376-378.

JONES, R. N. 1985. Are B chromosomes selfish? In: CavalierSmith, T. (ed.) The Evolution of Genome Size, pp. 397-425. John Wiley \& Sons, London.

JONES, R. N. 1991. B-chromosome drive. Am. Nat., 137, $430-442$.

MAISTRO, E. L., FORESTI, F., OLIVEIRA, C. AND ALMEIDA TOLEDO, L. F. 1992. Occurrence of B chromosomes in Astyanax scabripinnis paranae (Pisces Characiformes Characidae). Genetica, 87, 101-106.

MiAO, V. P., COVERT, S. F. AND VANETTEN, H. D. 1991. A fungal gene for antibiotic resistance on a dispensable ('B') chromosome. Science, 254, 1773-1776.

MizoGUCHI, S. M. H. N. AND MARTINS SANTOS, I. C. 1997. Macroand microchromosomes B in females of Astyanax scabripinnis (Pisces Characidae). Hereditas, 127, 249-253.

MOREIRA FILHO, O. AND BERTOLLO, L. A. C. 1990. Uma técnica alternativa para preparações cromossômicas de peixes. III Simpósio de Citogenética Evolutiva e Aplicada de Peixes Neotropicais. Botucatu, SP.

NUR, U. 1966. Harmful B chromosomes in a mealy bug population. Genetics, 54, 1225-1238.

NUR, U. 1977. Maintenance of a 'parasitic' B chromosome in the grasshopper Melanoplus femur-rubrum. Genetics, 87, 499-512.

ÖSTERgReN, G. 1945. Parasitic nature of extra fragment chromosomes. Bot. Notiser, 2, 157-163.

PARKER, J. S., JONES, G. H., EDGAR, L. AND WHITEHOUSE, C. 1989 The population cytogenetics of Crepis capillaris. II. The stability and inheritance of B chromosomes. Heredity, 63, $19-27$.

PARKER, J. S., JONES, G. H., EDGAR, L. AND WhITEHOUSE, C. 1991. The population cytogenetics of Crepis capillaris. IV. The distribution of $\mathrm{B}$ chromosomes in British populations. Heredity, 66, 211-218.

Plowman, A. B. AND BOUgOuRd, S. M. 1994. Selectively advantageous effects of $\mathrm{B}$ chromosomes on germination behavior in Allium schoenoprasum L. Heredity, $\mathbf{7 2}$, 587-593.

PORTO-FORESTI, F., OLIVEIRA, C., MAISTRO, E. L. AND FORESTI, F. 1997. Estimated frequency of B-chromosomes and population density of Astyanax scabripinnis paranae in a small stream. Braz. J. Genet., 20, 377-380.

RAYMOND, M. L. AND ROUSSET, F. 1995. An exact test for population differentiation. Evolution, 49, 1280-1283.

RoCON STANGe, E. A. AND ALmeida toledo, L. F. 1993. Supernumerary B chromosomes restricted to males in 
Astyanax scabripinnis (Pisces Characidae). Braz. J. Genet., 16, 601-615.

SALVADOR, L. B. AND MOREIRA FILHO, O. 1992. B chromosomes in Astyanax scabripinnis (Pisces Characidae). Heredity, 69, 101-106.

SHAw, M. W. 1984. The population genetics of the B-chromosome polymorphism of Myrmeleotettix maculatus (Orthoptera: acrididae). Biol. J. Linn. Soc., 23, 77-100.

SHAW, M. W. AND HEWITT, G. M. 1990. B chromosomes, selfish DNA and theoretical models: where next? In: Futuyma, D. \& Antonovics, J. (eds) Oxford Surveys in Evolutionary Biology, vol. 7, pp. 197-223. Oxford University Press, Oxford.

SOUZA, I. L. AND MOREIRA-FILHO, O. 1995. Cytogenetic diversity in the Astyanax cabripinnis species complex (Pisces,
Characidae). I. Allopatric distribution in small stream. Cytologia, 60, 1-11.

VICENTE, V. E., MOREIRA-FILHO, O. AND CAMACHO, J. P. M. 1996. Sex-ratio distortion associated with the presence of a $\mathrm{B}$ chromosome in Astyanax scabripinnis (Teleostei Characidae). Cytogenet. Cell Genet., 74, 70-75.

Viseras, E. AND CAMACHO, J. P. M. 1985. The B chromosome system of Omocestus bolivari: changes in B-behaviour in $\mathrm{M}_{4}$-polysomic B-males. Heredity, 54, 385-390.

white, M. J. D. 1973. Animal Cytology and Evolution, 3rd edn. Cambridge University Press, Cambridge.

ZURITA, S., CABRERO, J., LÓPEZ-LEÓN, M. D. AND CAMACHO, J. P. M. 1998. Polymorphism regeneration for a neutralized selfish B chromosome. Evolution, 52, 274-277. 